\title{
The Effect of Discovery Learning Method Towards Students' Learning Outcomes and Critical Thinking Skills in Primary School
}

\author{
Annisa'ul Mu'affifah, Ketut Prasetyo \\ State University of Surabaya \\ Surabaya, Indonesia \\ annisa.maffifah96@gmail.com
}

\begin{abstract}
The researchers decided to conduct this study since almost all elementary students considered social sciences very difficult in which the subject cannot be memorized easily and boring. One of the learning models which get the students involved in construction-based learning models and cooperative learning models is discovery learning. This study aims at ascertaining the effect of discovery learning the cooperative model towards the learning outcomes and critical thinking skill of the fourth graders in SDN Klakahrejo Surabaya.
\end{abstract}

Keyword-discovery learning; learning result; critical thinking

\section{INTRODUCTION}

The age becomes more advanced and growing and education becomes a major need for individuals to continue living and compete in the midst of the current globalization. Through education, the potential in a person can be developed in a fun learning environment and in accordance with his or her ability to have the desired quality of society and nation. Therefore, education is strengthened by the existence of educational design in the form of curriculum that always changes according to the time. The curriculum can be an educational response to the needs of society and nation in building the young generation of its people [1]

Social Sciences is one of the main subjects in elementary school, high school to college which has a very important role in knowledge and technology. Social Sciences is a mean to learn the concepts, nature and characteristics sourced from society and the environment, which can add a wider and deeper insight. The number of concepts that must be studied in this IPS material is needed to lead the young generation to be able to think critically.

Currently, to build a generation of high-thinking nationals and to develop self-potential, the Indonesian government implements the 2013 curriculum that emphasizes a scientific approach involving process skills in its learning. Through this scientific approach, students are expected to compete in the future based on the ability possessed, one of which is the ability to think critically. It states the need for the future competition where the learners' abilities are needed i.e. communication, creative and critical thinking skills.
Students need to find the truth amid the amount of information they get so that students are not only an object in the transfer of knowledge from teachers. However, in fact, students' critical thinking skills in Indonesia are still low. Based on the results of a survey by Alwasilah [2] 46\% respondents answered that the education system in Indonesia is not able to make students think critically.

In addition to the low critical thinking skills, students' learning outcomes, especially in the field of social science also become a consideration to see how far the ability possessed by students because the results of learning point to the learning achievement. Meanwhile, learning achievement is an indicator of the degree of change in student behavior [3]

Many students assume that social science is a field of study that saturates and fewer challenges students' learning interests. Such tendencies can also reduce student learning interest and may ultimately have an impact on the decline in learning outcomes. In addition, students are accustomed to memorizing compared to finding their own concepts on the material taught so that critical thinking skills are still low. Besides, learningcentered only on teachers or teacher-centered learning where to put teachers as a giver of knowledge for students, and how the delivery of knowledge tends to be dominated by lecture methods. The use of dominant lecture methods causes low student participation, student progress slowing down, student's attention and interest can't be monitored. With such conditions, it can cause student activity in critical thinking will be limited as well as the students' learning outcomes are less good. The presence of teachers in the learning process plays an important role, therefore teachers who are considered as facilitators should be able to create a fun atmosphere and learning activities.

Based on the results of the preliminary observations done by researchers at SDN Kalahrejo Surabaya on January 8, 2018, it was known that the minimum mastery criteria of Social Sciences subjects in grade IV was 75 . However, in fact, there were still many students who had not reached the minimum mastery criteria based on what had been established. The results of the evaluation conducted at the end of the Social Studies lesson showed that of 33 students, 23 of them got score under the minimum mastery criteria and only 10 students got the score above the minimum mastery criteria. It showed that 
$69 \%$ of students did not get the value that met the minimum mastery criteria. For the critical thinking of 33 students, there were only 9 students who were able to think critically and 24 other students who preferred self-pacification. The researchers assumed that the cause of the problem based on the data above was the low interest in learning in social studies subjects. Seen from preliminary observation of pre-research, the classroom learning tends to be passive, visibly lack of student interest in social studies subject in which many of the students paid less attention to the teacher's explanation because of the use of lecturing method which made the students quickly bored.

To overcome the low critical thinking skills and learning outcomes, it is necessary to make changes in the teaching and learning model so that the students are actively involved in the learning process and the teacher acts as the facilitator and mediator for the students. One model that can be used in improving the ability of critical thinking and student learning outcomes is the model of discovery learning with matrix comparison. Learning using discovery learning models can improve students' critical thinking skills because students are trained to observe, question, try, reason and communicate through their syntax [4] Learning with the discovery learning model requires students to be active in finding and discovering the concepts of knowledge gained through experience. A research conducted by [4] shows that the learning discovery learning model gave an effect of $28.23 \%$ on students' critical thinking skills.

According to the theory of learning developed by J. Piaget [5], individuals basically have the ability to construct their own knowledge. The knowledge constructed by children becomes meaningful knowledge. However, the knowledge gained only through the notification process will not be a meaningful knowledge that can only be remembered while it is then forgotten. For that reason, the researchers tried to implement a learning using discovery learning model. Discovery learning model is a learning model that emphasizes the process of discovery of knowledge data and facts, meaning data and facts so that the learning can be done independently. This kind of learning process will produce meaningful and continuing knowledge of student themselves. As in the cone of Edgar Dale's experience, the process of experiencing itself will contribute enormously to build an understanding for the learner. The discovery method was used in this study because it contains significant benefits, especially for: a. Helps students to improve and improve cognitive skills and processes. Discovery effort is key in this process, a person depends on how to learn; b. Knowledge gained through this method is very personal and powerful because it reinforces understanding, memory, and transfer; c. Fostering and developing the attitude of wanting to know better (curiosity); d. Reveals the cognitive, affective, and psychomotor aspects. In addition to use as the previous explanation, this discovery learning model also has many advantages, including: a. This technique is able to assist students to develop; multiply readiness, and mastery of skills in cognitive or student recognition processes; $b$. Students acquire knowledge that is very personal / individual that can be solid / deep behind in the soul of the student; c. Can arouse students' enthusiasm; $d$. This technique is able to provide opportunities for students to develop and advance in accordance with their respective capabilities; e. This technique is able to direct the way students learn, so more have a strong motivation to study harder.

The discovery learning model also makes students find their own concept of knowledge gained, so that student learning outcomes will increase. Problem-solving and selfdiscovery without special aid provide superior results because learners find new rules that are higher in degree. Therefore, it is important to encourage students to find solutions for their own problems [6]. A research conducted by [7] states that the discovery learning model is influential in improving student learning outcomes.

Based on the description above, the discovery learning model provides an illustration that the learning experience that students get through the process of experiencing directly or experiencing through artificial media which allows misperception can be avoided. Therefore, the learning process takes place in a fun way, and can improve student achievement.

In addition, to have the construction knowledge meaningfully, teachers should train students to think critically in analyzing and in solving a problem. The students who think critically are the students who are able to identify, evaluate, and construct arguments and be able to solve problems appropriately. Students with critical thinking will be able to help themselves or others in solving the problems faced. The efforts to train students' critical thinking skills is often excluded from the attention of teachers. It is proven by the learning activities conducted by teachers who provide more information, followed by discussions and exercises with very limited frequency. Critical thinking is needed in order to solve a problem in order to obtain a quick and precise decision.

Observing the problems presented above, this study applied a learning that was expected to condition students in such a way that students could be actively involved in learning. It was also expected to foster the cooperation among students as well as train students' critical thinking skills so that students are able to solve the problems encountered. For that, the learning applied was in the form of cooperative learning with discovery strategy. The objectives to be achieved in this study was to improve the learning outcomes and improve students' critical thinking skills as well as to know the opinions of students on cooperative learning with the methods of discovery applied.

Based on description background, in order to improve the ability of critical thinking and student learning outcomes as one of the solutions in learning activities, the authors were interested in conducting a research which related to the influence of Discovery Learning Method with matriculation comparison of learning outcomes and critical thinking skills of fourth grade Students in one primary school of SDN Klakahrejo Surabaya. Through this research, it was expected that it could improve the students' critical thinking skills and learning outcomes (cognitive).

\section{METHOD}

\section{A. Research design}

The type of the research used for this research was experimental research. This research was conducted to find out 
the influence of learning discovery learning model to social science learning achievement of fourth grade students of Klakahrejo Surabaya Primary School. With regard to that matter, it needed numerical data about student learning result, then data obtained were analyzed through statistics.

The research entitled "the influence of cooperative learning model of discovery learning type toward social learning outcomes of fourth grade students of Klakahrejo Surabaya" used quasi experimental design with non-equivalent control group design. This design was similar to the pretest-posttest control group design. However, in this design, the experimental group or the control group were not randomly selected. The experimental class was a class that used discovery learning model, while the control class did not use discovery learning model. The design of this study can be described in the following figure 1:

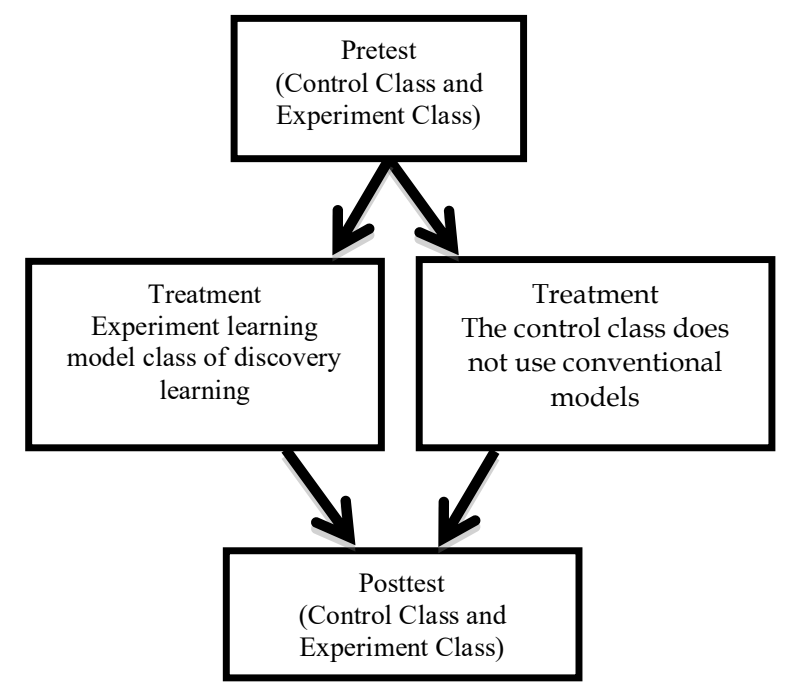

Fig 1. The design of quasi experimental design with nonequivalent control group design

The pretest was done to know the student's ability before being treated, and this pretest was tested to two classes namely experiment class and control class. The second step was the provision of treatment (treatment) which used discovery learning model in the experimental class and did not use discovery learning model in the control class. The next step was posttest which was tested to know the ability of students after being treated.

\section{B. Participant}

This research was conducted at Klakahrejo Surabaya primary school, Benowo sub-district, Surabaya city. The author chose the research location at Klakahrejo elementary school in Surabaya because the discovery learning model had never been used in the learning material of the long unit of measurement. The strategic location of research and the closeness to the center part of Surabaya made the access to the research easier and closer to the residence of the researchers. The principals and teachers also provided full support for the implementation of research at Klakahrejo Surabaya primary school.

The population involved the whole subject of research. Population in this research were all fourth grade student of elementary school Klakahrejo Surabaya. The sample in this study were students of class fourth grade (A) and fourth grade (B), Klakahrejo elementary school of Surabaya. In this case, the two classes were selected on the basis of equivalence in the odd semester of the 2017/2018 academic year.

\section{Data colleting technique}

The research instrument used was a test instrument. The test instrument used in this study was the test of learning material of the unit of measuring length. This test consisted of multiple choice questions for measuring the ability of material comprehension related to the long unit of measurement. The result of learning test of material understanding ability was arranged based on learning indicator which referred to the material of long measurement unit which was included in the scope of my hero's theme with the subtheme of my hero my pride for fourth grade of elementary school. The test of learning outcomes was done twice, including the pretest which was used to see the student's early ability and the posttest which was done to see student's ability after given the treatment.

A good instrument needed to meet the two important requirements that were valid and reliable [8] An instrument is said to be valid if it is able to measure what is desired. The research conducted used self-made instruments that had not been standardized, so it was necessary to test the validity of the instrument in order to produce suitable data.

The experts were asked for his opinion about the instruments that have been prepared. After the instrument was consulted with the expert, the next step was to conduct a test on the specified sample, then performed the analysis.

In calculating the validity of research instruments, the researchers used the formula of Product Moment as follows:

$$
r_{x y}=\frac{N \sum X Y-\left(\sum X\right)\left(\sum Y\right)}{\sqrt{\left\{\left(N \sum \mathrm{X}^{2}-\left(\sum \mathrm{X}\right)^{2}\right)\left(N \sum \mathrm{Y}^{2}-\left(\sum \mathrm{Y}\right)^{2}\right)\right\}}}
$$

After obtaining the result, the next rxy value was compared with the result $\mathrm{r}$ on the product moment table with $5 \%$ significance level. The item was valid if $r$ count $>r$ table.

The reliability refers to a sense that an instrument which is reliable enough to be used as a data-gathering tool because the instrument is good. The formula used to measure the reliability of test instrument of this study was the formula of K-R 21 namely:

$$
\mathrm{r} 11=\left(\frac{k}{k-1}\right)\left(1-\frac{M(k-M)}{k V t}\right)
$$

Appropriate data collection techniques were required to obtain suitable research data. The data collection techniques used in this study were the test results of learning (pretest and posttest). The pre-test question was double choice, with the appropriate material of the long unit of measurement on the theme of my hero and the subtheme of my hero my pride for the second lesson. This pre-test was given to the control class as well as the experimental class in the same form and number 
of questions. Th post-test given the shape and amount of the problem, was the same as the pretest. The post-test in the control class was given after the learning was completed by the teacher. Meanwhile, the post-test in the experimental class was given after the treatment was in the form of learning discovery learning model. This post-test aimed at determining the students' learning outcomes after treatment was given.

In the study, the data analysis was an activity performed after all the data from the respondents collected. These data needed to be processed immediately to find out the results of the proposed research variables.

The sample of the normality test was performed to test the normality of the sample. This study tested the normality of data through Liliefors formula. The use of Liliefors test was because it was relatively easy and accurate.

After doing the normality test, the next step was the homogeneity test. Testing the homogeneity of the sample became very important if the researchers intended to generalize for the results of his research and research that research data taken from separate groups coming from one population. The homogeneity test in this study was calculated using $\mathrm{F}$ test, with the following formula:

$$
F_{\text {hitung }}=\frac{V b}{V k}
$$

The decision making and conclusion drawing on the $\mathrm{F}$ test were conducted at the 0.05 significance level. In the homogeneity test, the expected price $F$ was the insignificant $F$ value, which was the lower $F_{\text {empirical }}$ price than the $F_{\text {teoritic }}$ price contained in the table (Winarsunu, 2012: 100). The rule of the decision was that if $\mathrm{F}_{\text {count }}<\mathrm{F}_{\text {table }}$ then the homogeneous data distribution.

The data obtained from this research were test data obtained from the pre-test and post-test. To see the effect of video media on student learning outcomes, different test analysis techniques or t-Test were used. Here is the t-Test formula used:

$$
t=\frac{\overline{X_{1}}-\overline{X_{2}}}{\sqrt{\frac{S_{1}^{2}}{n_{1}}+\frac{s_{2}^{2}}{n_{2}}}}
$$

\section{RESULTS AND DISCUSSION}

\section{A. Expediency/ properness}

In this action research, learning administration used included: syllabus, lesson plan (RPP), students' activity sheet, students' material learning, and students' critical thinking skill sheet. Before they were used, sets of equipment were validated by people who expert on those fields. All of the learning devices and research instruments, in general, could be categorized suitable with less revision, and proper to use in research.

\section{B. Research Result Description}

The implementation of the research conducted was in accordance with the research design that had been listed in chart 1. The implementation of the study began by doing pretest activities which was followed by treatment, and then performing posttest activities.

The pre-test was done to the control class of fourth grade (A) consisting of 34 students and the experiment class of fourth grade B consisting of 34 students as well. This activity was held at Klakahrejo Surabaya elementary school on January 25, 2018, at 10.00-11.00 AM in the fourth grade (A) and January 252018 at 11.10-12.10 AM in the fourth grade (B). Each class was given one hour to answer multiple pre-test questions that had passed the validity test and had been supervised by the teachers and researchers.

The treatment was carried out in the experimental class when the learning process took place through discovery learning model as a model in teaching the material of long measuring unit on the theme of my hero subtheme of my hero my pride in the second learning. The treatment in the experimental class was held on Wednesday and Thursday, 31 January and 1 February 2018. Meanwhile, in the control class, the teaching and learning process took place as usual by applying learning in accordance with the lesson plan that was implemented through textbooks. The treatment in first-class control meeting was held on Thursday, February 1, 2018. Then, the second meeting was held on Friday, February 2, 2018 .

Different treatment was done to obtain a comparison data between the learning process by using discovery learning model with the learning process that did not use the learning model of learning discovery learning, which was limited to the material unit measuring the length of the hero theme with the sub theme of my hero my pride in learning 2.

After the treatment was given, the next step was to carry out the post-test. It was done to determine the learning outcomes achieved after carrying out the learning activities 2 on the theme of my hero with the sub theme of my hero pride in both classes including the one used discovery learning model and the one which did not use the learning model. The Post-test activities were conducted after the lessons were held, each on 5th February 2018 at 11-12.00 AM for the control class and February 6th at 11.00-12.00 AM for the experimental class. As a result of this activity, it was obtained the data on post-test results on the treatment given to the fourth grade A students as the experimental group and fourth grade B students as the untreated control group.

The results obtained were then analyzed by using the homogeneity test, normality test, and t-test technique to obtain accurate research data.

To know the level of homogeneity of a control class and experiment class, the researchers used pre-test result data which had been implemented. The values were analyzed by using the formula and drawn a homogeneous decision or not 
the sample. The decision making and conclusion of the homogeneity level was done by doing a comparison of $\mathrm{F}_{\text {count }}$ and $F_{\text {table }}$ value in which the $F_{\text {value }}$ ratio was done at 0.05 significance level. The rule of the decision was that if $\mathrm{F}_{\text {count }} \leq$ $\mathrm{F}_{\text {table }}$ then the data distribution is declared homogeneous.

Using $\mathrm{db}=26$ and 26 obtained $\mathrm{F}$ theoretic price of the table of 1.95 at the $5 \%$ significance level and $\mathrm{F}$ max, it was obtained a value of 1.445 from the above calculation. From the data, it can be seen that $\mathrm{F}$ max was smaller than $\mathrm{F}$ theoretic $(1.137$ $<1.85$ ), therefore, the rule of the homogeneity test decision was that if $\mathrm{F} \max <\mathrm{F}$ theoretic, then the data distribution was declared as homogeneous.

The calculation of the data normality test was done in control class and experiment class. Based on the pretest, normality test activity in control and experiment class were described as follows:

Table 2. Calculation of the Normality of Pretest Result of the Control Class and the experiment class

\begin{tabular}{|c|c|c|}
\hline \multirow{2}{*}{ Statistic } & \multicolumn{2}{|c|}{ Pre-test } \\
\cline { 2 - 3 } & Experiment & Control \\
\hline $\mathrm{N}$ & 34 & 34 \\
\hline Mean $(\bar{x})$ & 50,147 & 49,529 \\
\hline $\begin{array}{c}\text { Standard } \\
\text { deviation }\end{array}$ & 11,452 & 10,234 \\
\hline $\mathrm{L}_{\text {count }}$ & 0,136 & 0,148 \\
\hline L table & 0,886 & 0,886 \\
\hline Conclusion & Normal Distribution & Normal Distribution \\
\hline
\end{tabular}

From the result of normality test of learning result of pretest of experiment and control class, the result was given as follows: With the same number of students each class amounted to 34 students, then average was 50,147 for experimental class and 49,529 for control class. then the standard deviation is 11,452 for the experimental class while the control class is 10,234 . Finally, it was known that the $\mathrm{L}_{\text {count }}$ value for the experimental class and the control class was 0.136 and 0.148. Since t-count was greater than t-table $(0.886)$. Based on the result of the above calculation, it could be concluded that the experiment class and control class values were normally distributed.

The posttest normality test in the experimental class gave increase to the following data:

TABLE 3. CALCULATION OF POSTTEST NORMALITY OF EXPERIMENT CLASS AND EXPERIMENT CLASS

\begin{tabular}{|c|c|c|}
\hline \multirow{2}{*}{ Statistic } & \multicolumn{2}{|c|}{ Post-test } \\
\cline { 2 - 3 } $\mathrm{N}$ & Experiment & Control \\
\hline Mean $(\bar{x})$ & 85,823 & 34 \\
\hline $\begin{array}{c}\text { Standard } \\
\text { deviation }\end{array}$ & 7,424 & 80,058 \\
\hline L count & 0,202 & 7,240 \\
\hline L table & 0,886 & 0,239 \\
\hline Conclution & $\begin{array}{c}\text { Normalitas } \\
\text { Distribution }\end{array}$ & $\begin{array}{c}\text { Normalitas } \\
\text { Distribution }\end{array}$ \\
\hline
\end{tabular}

From the result of the normality test of learning result of the pretest of experiment and control class, it was obtained the results as follows: With the same number of students of each class, it was amounted of 34 students. Then, the average score was 85,823 for experiment class and 80,058 for the control class with the standard deviation of 7,424 for the experimental class while, for the control class, the standard deviation was 7.240. Finally, the $\mathrm{L}_{\text {count }}$ values for the experimental and control classes were 0.239 and 0.202 . Since $\mathrm{L}_{\text {count }}$ was greater than L-tabel (0.886), the result of the above calculation, it can be concluded that the experiment class and control class values were normally distributed.

The use of t-test technique in experimental research was intended to determine whether there was an influence in the treatment of the use of video media to student learning outcomes dealing with material unit of measuring the length and with the theme on the hero theme with the sub theme of my hero pride that was taught in fourth grade in elementary school Klakahrejo Surabaya by looking at the difference in the average calculations between the experimental and control groups. In this case, the researchers used 2 classes to be subjected for this research including fourth grade- $A$ as the control class and fourth grade-B as the experimental class. To find the effect, the average difference test (t-test) was calculated using manual calculation.

The calculation of different test (t-test) in this study was given as follows:

$$
\begin{aligned}
& t=\frac{\overline{X_{1}}-\overline{X_{2}}}{\sqrt{\frac{S_{1}^{2}}{n_{1}}+\frac{s_{2}^{2}}{n_{2}}}} \\
& t=\frac{86,02941-80,0588}{\sqrt{\frac{59,605}{34}+\frac{52,420}{34}}} \\
& t=\frac{5,97061}{\sqrt{1,75+1,54}} \\
& t=\frac{5,97061}{\sqrt{3.29}} \\
& t=\frac{5,97}{1,81} \\
& t=3,29
\end{aligned}
$$

From the calculation above dealing with the data, it could be found that $=5.443$ and $d . b=66$. Then, it was consulted with t-table with d.b $=60$ (which approached d.b $=66$ ) to $5 \%$ significance level that obtained t-table value of 2,000. So, it can be seen that t-counting obtained was greater than t-table (3.29> $2,000)$. Thus, it can be concluded that Ha was accepted and Ho 
was rejected. In other words, the use of discovery learning model gave a significant effect on student learning outcomes of the unit of measuring material in grade IV SDN Klakahrejo Surabaya, in which the class that got treated using a learning model had a higher grade average than the class that was not taught using discovery learning model.

Based on the result of analysis of pre-test and post-test data, it was known that the control class has the average value of pre-test 49,529 while the average result of post-test was 80,058 . For the experiment class, it had a result of average pretest 50,147 and the average result the post-test was 85.823. Based on the results of the analysis along with the explanation above, it can be assumed that the average value obtained by each class, both control class and experiment class, had different values. There was an increase in the learning scores in the experimental class after being given the treatment in the form of discovery learning model with the theme of my hero in the fourth grade B class of SDN Klakahrejo Surabaya.

The following is the students' critical thinking skill result on every cycle based on the achievement indicator.

TABLE 3 .

\begin{tabular}{|l|c|c|c|c|}
\hline \multirow{2}{*}{ Kind of activity } & \multicolumn{3}{c|}{ Observation } & \multirow{2}{*}{ Total } \\
\cline { 2 - 4 } & $\begin{array}{c}1^{\text {st }} \\
\text { cycle }\end{array}$ & $\begin{array}{c}2^{\text {nd }} \\
\text { cycle }\end{array}$ & $\begin{array}{c}3^{\text {rd }} \\
\text { cycle }\end{array}$ & \\
\hline Elementary clarification & 426 & 441 & 467 & 1.334 \\
\hline Basis for the decision & 420 & 433 & 456 & 1.309 \\
\hline Interference & 431 & 451 & 471 & 1.353 \\
\hline Advanced clarification & 406 & 433 & 461 & 1.300 \\
\hline Supposition and integration & 400 & 432 & 455 & 1.287 \\
\hline Total & 2.083 & 2.190 & 2.310 & 6.583 \\
\hline Percentage & $72 \%$ & $76 \%$ & $80 \%$ & $76 \%$ \\
\hline
\end{tabular}

Every students' critical thinking skill indicator resulted differently. Based on table 3, every critical thinking skill indicator, which was specified, always increased starting from the first, the second, and the cycle. It can be found that there was an improvement on students' critical thinking skill in the 1st cycle that was $72 \%$, 2nd cycle that was $76 \%$, and the $3 \mathrm{rd}$ cycle that was $80 \%$

\section{CONCLUSION}

Based on the results of data analysis of research findings, it can be seen that the learning discovery learning model presented was able to provide a significant improvement to the results of student learning fourth grade $B$ which was the experimental group. The result of fourth grade B students learning tended to have a higher average of score than the result of fourth grade A study as a control group. It indicated that the learning model was able to influence and have a positive impact towards the learning outcomes.

Learning discovery learning model that was used could improve students' understanding related to the material of long unit of measure, because at the time of learning process, the students were not only required to be active. The students need also to be creative in making a question and there were games as the encouragement during the learning process.

Based on research activities that had been done, the success of learning and student learning outcomes is supported by the readiness of equipment owned by the school, interest, and attention of students who are increasingly large if the learning is done with a fun learning model and create active students.

In the research, that has been conducted, it can be proved that the discovery learning model could give positive impact towards the students' learning outcomes, in which the learning model also became a tool for clarifying, simplifying, and accelerating the delivery of the learning materials.

Based on the activity on the research about the influence of the use of discovery learning model to the material of long measuring unit on the theme of my hero in the fourth grade of Klakahrejo Surabaya primary school and supported by the result of data analysis on the pre-test and post-test value indicating that the experimental class had the average value average pre-test of 50,047. After being treated in the form of learning discovery learning model, the average value of student learning increased to 85,823 . In line with the results of the data analysis using t-test, it was shown the t-count price was 3.29 while the value of $t$-table with 5\% significance level was 2,000 . It showed that the value of $\mathrm{t}$-count was greater than $\mathrm{t}$-table or $\mathrm{t}$ count 3.29>t-table 2,000. Thus, it could be concluded that the use of discovery learning model to the learning outcomes of the unit of measuring the length of fourth-grade students Klakahrejo Surabaya elementary school gave a significant effect on the learning outcomes in which there was a positive impact based on the improvement of the students' learning outcomes.

\section{REFERENCES}

[1] D. Daryanto, "Pendekatan Pembelajaran Saintifik Kurikulum 2013," Yogyakarta Gava Media, 2014.

[2] Agustina, "IQ Prestasi Belajar Di Sekolah, Dan Kecerdasan Emosional Siswa Remaja.," J. Provitae., vol. 2, 2006.

[3] O. Hamalik, "Belajar dan Teori Belajar,” Jakarta Bumi Aksara, 2008.

[4] F. A. Pratiwi and R. Rasmawan, "Pengaruh Penggunaan Model Discovery Learning Dengan Pendekatan Saintifik Terhadap Keterampilan Berpikir Kritis Siswa SMA," J. Pendidik. dan Pembelajaran, vol. 3, no. 7, 2014.

[5] W. Sanjaya, "Strategi pembelajaran berorientasi standar proses pendidikan." Jakarta: kencana, 2006.

[6] S. Nasution, Berbagai pendekatan dalam proses belajar dan mengajar. PT. Bina Aksara, 2000.

[7] R. Melani, H. Harlita, and B. Sugiharto, "Pengaruh Metode Guided Discovery Learning Terhadap Sikap Ilmiah dan Hasil Belajar Kognitif Biologi Siswa SMA Negeri 7 Surakarta Tahun Pelajaran 2011/2012," Pendidik. Biol., vol. 4, no. 1, 2012.

[8] A. Suharsimi, "Prosedur penelitian suatu pendekatan praktik," Jakarta: Rineka Cipta, 2006.

[9] Sugiyono, “Statistika Untuk Penelitian,” Bandung: Alfabeta, 2013. 